\title{
Cultural aspect in the course materials for the vocational training programs
}

\author{
Lilia R. Ismagilova ${ }^{1 a}$, Irina M. Solodkova ${ }^{2}$ and Elena V. Grigorieva ${ }^{3}$ \\ ${ }^{1}$ Department of Foreign Languages, Institute of Management, Economics and Finances, Kazan \\ Federal University, Russia \\ ${ }^{2}$ Department of Foreign Languages, Institute of Management, Economics and Finances, Kazan \\ Federal University, Russia \\ ${ }^{3}$ Department of Foreign Languages, Institute of Management, Economics and Finances, Kazan \\ Federal University, Russia
}

\begin{abstract}
Competitiveness on a labour market makes specialists be involved in self-development projects connected with widening their background knowledge. Vocational training programs provide foreign language education to help specialists be promoted in multinational companies as language and culture misunderstanding are seen as real career trials. The paper suggests the analysis of the cultural aspect in coursebook materials for the vocational training program at the Educational Center for Professional Communicative Training of Kazan Federal University. The research aims at collating the syllabus requirements to the cultural aspect in a coursebook materials. The data obtained throughout the analysis afforded ground for deciding on the coursebook that best meets syllabus requirements due to multi-aspect approach to cultural knowledge acquisition. At the end of the vocational training course students would demonstrate cultural knowledge which allows to adapt to foreign environment, to overcome mentality differences in doing business, traditions and customs thus satisfying learners' realworld professional demands.
\end{abstract}

Keywords: cultural aspect, vocational training programs, student, syllabus, coursebook material, socio-cultural competence, language education

\section{Introduction}

Globalization and the processes following it like off-shoring and great job migration,' the increase of international students in higher educational institutions, the flow of migrants from non-CIS countries into the territory of the Russian Federation' make environments become more multicultural [2]. Specialists are required to relocate and be able to embed themselves into a foreign culture adopting its rules, norms of behaviour and social

\footnotetext{
${ }^{\text {a }}$ Corresponding author: liliaismg@gmail.com
} 
dimensions. English language serves as a lingua franca for professionals in different spheres allowing them to communicate successfully [8]. They should have 'English language ability at the level to guarantee successful professional communication' [8].

It has transformed itself into varieties of 'Englishes' and in fact communication between non-native speakers of English is far greater in frequency, amount, and significance as well as the number of speakers today [5,7].

Consequently, English language acquisition is inconceivable without acquisition of cultural knowledge as 'language and culture must be treated as inseparable constructs' [3, $10]$.

The importance of the matter is stressed in the report by the Modern Language Association Ad Hoc Committee on Foreign Languages. It highlights the equality of cultural knowledge and linguistic competence if 'one wishes to understand people and their communities' [13].

The crucial importance foreign language acquisition and cultural knowledge gained in Russia was due to 'the participation of Russia in international organizations as BRICS, WTO, APEC, SCO, as well as, involvement in foreign trade' [15]. Under these circumstances country needs specialists who can act in foreign environments regardless cultural and social differences. This made the government together with university officials brought up a question of updating the programs on foreign language teaching, changing the curriculum, renovating the tools and materials used for the language studies, developing vocational training courses to bridge the gap between what students want to know and what they really need to learn to become successful in the future career.

Vocational training programs delivered at tertiary educational institutions strive for graduating specialists who can use a foreign language primarily for communication and therefore incorporating multiple levels of language, including pragmatics [1].

Reviewed researches allow concluding that the issue of cultural aspect in teaching English as a foreign language is not a very recent trend. There could be observed the tendency of increasing the amount of teaching materials that would enable educators to implement the practices of combining language matters with cultural aspects in the classrooms. University executives and teaching community should choose those materials, textbooks, in particular, which incorporate the main theories of foreign language acquisition.

This research paper aims at providing the analysis of the cultural aspect in a course book materials for the vocational training program delivered at tertiary educational institution. Authors employed the features distinguished by the Common European Framework of Reference for Languages to trace the categories outlined in the examined textbooks.

\subsection{Research question}

Basing on literature review the authors of the study assigned a research question, that is:

1. To what extent is cultural aspect presented in the course materials for the vocational training programs?

\subsection{Problem statement}

Vocational training program at the Educational Center for Professional Communicative Training of Kazan Federal University supplies foreign language education to help specialists adapt to the cultural peculiarities and later be promoted in multinational companies. The target audience of the discussed vocational training program is the graduates of the business schools working for local or international companies and who have a necessity to be equipped with translation skills. 
The significance of cultural aspect in teaching students of vocational training program is explained by the following:

- expansion and broadening of intercultural communications;

- development of self-awareness to overcome stereotypes and prejudices and establish intercultural understanding between nations;

- the formation of linguistic and cultural competence to integrate new experiences into one's own cultural system.

Thus, course materials are thoroughly selected to serve the above mentioned purposes providing comprehensive and complete perception of culture, language and career.

In higher education and especially in a foreign language classroom, "the textbook is one of the many tools used for learning" [14].

Undoubtedly, textbooks have considerable influence on classroom practice forming the core of the most teaching programs [5]. Some teachers use them as the main tool, others as supplementary resource that helps to get a flow of topics studied throughout the lesson. No matter what role textbooks have, they would always be 'the most powerful device' [12].

Printed textbooks are more frequently substituted by digital versions as they are more compact, comfortable and available everywhere, as well as easier to be used in large groups. Besides, 'textbooks are outdated as soon as they are printed, apps and websites can be constantly updated" [10]. We agree with Velde \& Ernst who say that "print books are here to stay; e-books will enhance access to more science and research" [16].

The authors of the research opted for printed versions of the textbooks for several accounts: all our students are supplied with printed textbooks which are issued at the beginning of an academic year; it is easier to return to the cultural aspect that was studied before for revision or clarification; textbooks are rarely lost as handouts and are not dependent on Internet connection if stored online; they allow students to structure the material in no time referring to the necessary page and section.

A course book for teaching English presents a structured selection of topics suited to meet the needs of a certain category of learners, their level of language proficiency as well as the sphere of interests. Being divided into subsections, textbooks provide tasks to practice different language skills: reading, writing, listening, speaking. Following the theory of combining language competency and cultural one, each subsection of a studied unit should possess cultural aspect allowing students to immerse into foreign culture progressively, not necessarily of English-speaking countries. Considering the specificity of teaching a foreign language textbooks perform several interrelated functions: informative, motivating, pragmatic and controlling intended to optimize the achievement of goals. So, all tasks, containing cultural information have to envisage the discussed requirements.

The reviewed literature on the researched issue did not supply with the criteria used to estimate the quality and the scale of the cultural aspect presented in the course books for teaching English at vocational training programs. Basing on authors' experience and relying on their teaching flair they took a chance to form out the requirements to the cultural content used in the textbooks. First and foremost aspect is the authenticity of the material presenting cultural information; then comes association with the profession acquired and the various fields of science and technology correlating with it; all textbook materials should be designed to stimulate students' motivation for acquiring cultural information and later mastering it in communication in a foreign language in their professional field; the textbook's material should replenish the absence of foreign language environment, procure the conditions for communication, organizing the interaction of communicants as imitative authentic communication and serve as a basis for the future implementation of certain social roles by communicants as professionals; textbook's tasks with cultural content have to provide students with the availability of self-control and self-correction.

We are strongly convinced that all sections of the units included into a textbook could contain cultural aspect, no matter if it is a grammar exercise or filling in the gaps 
vocabulary practice. As long as there is a link between studied situations, real work and culture peculiarities students would get experiences that can enrich their language and cultural competency levels.

The provisions issued defined the motives for examining the course book materials used at vocational training program with the aim to distinguish the most affordable ones.

\section{Method}

The findings reported in this research are based on literature review aimed to clarify the problem statement and two stage survey. The first stage was supposed to provide the analysis of qualitative data for 3 Business English course books of upper-intermediate level produced by leading publishing houses: "Market Leader" by Pearson Longman, "Business Result" by Oxford University Press and "Intelligent Business" by Pearson Longman. The choice of this course books range was stipulated by co-decision of teaching staff for the vocational training program at the Educational Center for Professional Communicative Training of Kazan Federal University as they are among up-dated textbooks for Business English. The content of these course books was investigated from the social-cultural angle. The main data collection tool at this stage was SWOT analysis to reflect advantageous and disadvantageous features.

The second stage entailed analysis of socio-cultural features in course books creating the potential for researchers to generate quantitative data. In this context the researchers were particularly interested in the following features distinctively characteristic of a society adjusted by Common European Framework of Reference for Languages: everyday living; living conditions; interpersonal relations; values, beliefs and attitudes; body language; social conventions; ritual behaviour [4].

The data obtained throughout the above mentioned methods afforded ground for deciding on the course book that best meet syllabus requirements due to multi-aspect approach to cultural knowledge acquisition.

\section{Findings}

Having more than ten years of teaching experience as teachers of English, we could point several widespread drawbacks of the textbooks that are used at the lessons: cultural aspect in the textbooks is not presented in the amount that is adequate to meet the needs of the curriculum. Supplementary handouts are required. It provides extra workload for teachers and is time consuming to find worksheets matching the discussed topics; tasks lack real life expressions and vocabulary; there are usually no images which could help students visualize the cultural aspect; video support does not always supply students with the peculiarities of body language, gestures, mimics; from the audio tasks it is not always clear what country of origin the speaker's accent comes from; representatives of several countries are rarely presented in one task simultaneously.

The SWOT analysis gave the overall picture of cultural representation in the whole set of the courses as a set (including video support, supplementary books and DVD-ROMs) in Tables 1,2 and 3. 
Table 1. Market Leader SWOT

\begin{tabular}{|c|c|}
\hline STRENGTHS & WEAKNESSES \\
\hline $\begin{array}{l}\text { - provides multiskills training of cultural } \\
\text { awareness; provides video support to get } \\
\text { patterns of behaviour and non-verbal means } \\
\text { of communication; has a special section } \\
\text { "Working across cultures" to teach the } \\
\text { cultural difference in doing business; } \\
\text { contains audio with different accents; has a } \\
\text { special business skills section }\end{array}$ & $\begin{array}{l}\text { - the business skills studied are } \\
\text { westernized; not all topics highlight the } \\
\text { cultural aspect of business; case studies do } \\
\text { not give the background information on the } \\
\text { business culture of the countries discussed }\end{array}$ \\
\hline OPPORTUNITIES & THREATS \\
\hline $\begin{array}{l}\text { - provide useful web links skills; } \\
\text { Youtube hosts international videos on the } \\
\text { topics of the book; } \\
\text { - English becomes an international } \\
\text { language to build cultural dialogue; } \\
\text { - skills and across cultural sections } \\
\text { could be used as independent course; } \\
\text { - continuous globalization of business; } \\
\text { - does not give the comparison of } \\
\text { cultures }\end{array}$ & $\begin{array}{l}\text { - business realities are changing too } \\
\text { rapid; } \\
\text { - the textbook is not tailored to the } \\
\text { cultural needs of individual student; } \\
\text { - localization of business traditions } \\
\text { - }\end{array}$ \\
\hline
\end{tabular}

Table 2. Intelligent business SWOT

\begin{tabular}{|c|c|}
\hline STRENGTHS & WEAKNESSES \\
\hline $\begin{array}{l}\text { - cultural aspect is taught within the } \\
\text { main topic of the unit; examples are not of } \\
\text { abstract nature; } \\
\text { - cultural aspect is presented in a } \\
\text { separate section and within the text and } \\
\text { listening tasks; } \\
\text { - covers common, highly discussed } \\
\text { topics; } \\
\text { - has a video support to develop socio- } \\
\text { cultural knowledge; } \\
\text { - contains the comparison of cultures }\end{array}$ & $\begin{array}{l}\text { - cultural aspect ranks the last place in } \\
\text { the list of tasks; } \\
\text { - the patterns of behavior are taken from } \\
\text { the western business culture; } \\
\text { - insufficient cultural information in the } \\
\text { case studies briefs }\end{array}$ \\
\hline OPPORTUNITIES & THREATS \\
\hline $\begin{array}{l}\text { - challenges students with out of book } \\
\text { research; } \\
\text { - business skills book does not depend } \\
\text { on the content of the textbook; } \\
\text { - } \quad \text { has a website with updated texts }\end{array}$ & $\begin{array}{l}\text { - tasks on cultural differences aren't } \\
\text { based on students' needs; } \\
\text { - demographic shifts change the culture } \\
\text { of countries and the book doesn't keep up } \\
\text { with that; } \\
\text { - the change of economic environment } \\
\text { and demography }\end{array}$ \\
\hline
\end{tabular}


Table 3. Business results SWOT

\begin{tabular}{|c|c|}
\hline STRENGTHS & WEAKNESSES \\
\hline $\begin{array}{l}\text { - cultural aspect is represented in all } \\
\text { activities: reading, writing, speaking, } \\
\text { listening; } \\
\text { - has "business communication skills" } \\
\text { section based on cultural aspect; } \\
\text { - section "practically speaking" - good } \\
\text { opportunities for sounding more natural } \\
\text { when students speak English; } \\
\text { - a wide range of countries involved are } \\
\text { used as examples }\end{array}$ & $\begin{array}{l}\text { - some topics don't reflect the cultural } \\
\text { aspect; } \\
\text { - few comparisons of culture; some } \\
\text { information is outdated; } \\
\text { - doesn't have a separate skills book; } \\
\text { contains discrepancy of students religious } \\
\text { beliefs and content of the texts; } \\
\text { - doesn't always consider the individual } \\
\text { students cultural needs in group tasks }\end{array}$ \\
\hline OPPORTUNITIES & \\
\hline $\begin{array}{l}\text { - considers business skills on a global } \\
\text { scale that can help students communicate } \\
\text { more accurately in real work situations; } \\
\text { - possesses video support on YouTube, } \\
\text { provides interactive workbook for } \\
\text { practicing the language and skills in work }\end{array}$ & $\begin{array}{l}\text { - features of cultural knowledge are } \\
\text { limited; } \\
\text { - global changes in economy, culture, } \\
\text { national identity, etc.; } \\
\text { - orientalization of Europe }\end{array}$ \\
\hline
\end{tabular}

Examining the Strengths we have noted that all three coursebooks provide multi skills approach to cultural acquisition, contain audio provision to enhance cultural awareness and have video support giving details on body language, mimics and other behavioral information. Business skills sections in the textbooks enable obtaining and training communication skills necessary to be adequate in the real business situations, Intelligent Business even developed Skills books that could be used as an independent course. Market Leader, however, has a special section Working Across Cultures with an aim to encourage students to dialogue in the companies with international staff.

As for the Weaknesses we should note that in all three sets of coursebooks the business skills studied are westernized, though Intelligent Business gives some theoretical insight in the other cultures no practical output is followed. Some topics do not touch upon the cultural aspect of business directly and case studies do not give the background information on the business culture of the countries discussed that hurdles overall understanding the situation.

Considering the Opportunities, on the other hand, with English becoming lingua franca these business courses are getting additional value and the updates and YouTube support provide extra availability and recognitions. Thus, the materials produced by different cultures could be discussed and compared and English is shown in action as a language to build a dialogue of cultures.

The Threats revealed the overall problems of the course materials: the business realities are changing too quickly for any update to follow; the courses are not tailored to the cultural needs of individual student and may contradict and even hurt the cultural and religious perspectives; localization of business traditions that prevents unification of any rules in conducting business; demographic, cultural and social changes due to recent migration wave that make any value and cultural shifts unpredictable.

Hence, all three examined courses possessed high potential for study strategy with their individual advantages and drawbacks.

According to Common European Framework of Reference for Languages distinguishes social-cultural features as: everyday living (food and drink, meal times, public holidays; leisure activities); living conditions (living standards, welfare arrangements); interpersonal relations (relations between sexes, family structures and relations, relations in work 
situations); everyday living (race and community relations, relations among political and religious groupings); values, beliefs and attitudes (national identity, social class; occupational groups, minorities); body language; social conventions (punctuality, presents, dress, behavioral and conversational conventions and taboos); ritual behavior (birth, marriage, death, celebrations, festivals, dances, discos, religious observances and rites) [4]. We examined the textbooks only to define the percentage of cultural aspect features discussed above presence, but for the body language as this aspect is available with face-toface communication or video content.

The results highlighted that cultural aspect is studied in the discussed textbooks in almost equal proportion (Market Leader - 46\%, Intelligent Business - 40.2\%, Business results $44.2 \%$ ). Examining the features in Table 4, it is clear that across all three textbooks interpersonal relations consistently receive attention, particularly due to the sections devoted to working relations' establishment. Values, beliefs and attitudes got considerable amount of attention especially in the case studies and speaking sections. Everyday living and living conditions were presented merely equal and get far less attention as the main subject of the textbooks is business. And, finally, social conventions and ritual behavior received the least attention from the authors of the textbooks. The probable explanation is less conscious desire to focus on taboos and religious observances in fast changing world of demographic shifts.

Table 4. Socio-cultural knowledge features comparative analysis

\begin{tabular}{lccc}
\hline Features & Market Leader & Intelligent Business & Business Result \\
\hline everyday living & $9.6 \%$ & $7.4 \%$ & $6.5 \%$ \\
living conditions & $13.3 \%$ & $14.3 \%$ & $17.6 \%$ \\
interpersonal relations & $44.3 \%$ & $43.2 \%$ & $48.8 \%$ \\
values, beliefs and & $23.5 \%$ & $25.8 \%$ & $17.6 \%$ \\
attitudes & & & $4 \%$ \\
social conventions & $5.4 \%$ & $5.8 \%$ & $5.5 \%$ \\
ritual behaviour & $3.9 \%$ & $3.5 \%$ & \\
\hline
\end{tabular}

\section{Discussion and conclusion}

This study investigated business English textbook regarding cultural aspects they give attention to. It has been examined that the textbooks give most attention to interpersonal relations, values, beliefs and attitudes, while ritual behavior and social conventions gets minimal degrees of attention. It has also been distinguished that all studied textbooks envisage similar trend in presenting socio and cultural knowledge. The obtained results would help educators to enhance the amount of cultural information to provide comprehensive socio-cultural education.

It could be predicted that at the end of the vocational training course students would demonstrate cultural knowledge which allows to adapt to foreign environment, to overcome mentality differences in doing business, financial and law matters, get an insight of traditions and customs thus satisfying learners' real-world professional demands. As a result the graduates of the vocational program will acquire the cultural inhering, tolerance and become culturally responsive personalities. They would easily organize their speech and non-speech behavior adequate to the tasks of communication and in accordance with its terms and conditions. 


\section{References}

1. Bardovi-Harlig. One functional approach to second language acquisition: The conceptoriented approach. In B. VanPatten \& J. Williams (Eds.). Theories in second language acquisition: An introduction. New York: Routledge. pp. 57-76, (2007).

2. T. A. Baklashova, E. M. Galishnikova, L. V. Khafizova. Formation of Student's Tolerance in Multicultural Environment When Teaching a Foreign Language (KFU Experience, Kazan, Republic of Tatarstan, Russia. The European Proceedings of Social \& Behavioural Sciences, Vol. 12, EpSBS e-ISSN: 23571330, pp. 38-44, (2016).

3. H. Byrnes. The cultural turn in foreign language departments: Challenge and opportunity. Profession 2002, pp.114-129, (2002).

4. Common European Framework of Reference for Languages: Learning, Teaching, Assessment, Cambridge University Press, ISBN : HB 0521803136 - PB 0521005310 www.uk.cambridge.org/elt

5. D. Crystal. English as a Global Language. Cambridge: Cambridge University press, (1997).

6. McDonough \& Shaw. Material and methods in ELT. Oxford: Blackwell, (1993).

7. D. Graddol. The Future of English? British Council, (1997).

8. E. V. Grigorieva, L. R. Ismagilova, I. M.Solodkova. Comparative analysis of oral and computer based types of assessment in teaching English for students of economics, business and finance. ERPA INTERNATIONAL CONGRESSES ON EDUCATION 2015 (ERPA): SHS Web of Conferences Vol. 26, Art. №: UNSP 01131, (2016).

9. L. R. Ismagilova, O. V. Polyakova. The problem of the syllabus design within the competence approach based on the course "English for Master Degree Students in Economics (advanced level)". Procedia - Social and Behavioral Sciences 152, pp.1095 - 1100, (2014).

10. C. Kramsch. Context and culture in language teaching. Oxford: Oxford University Press, (1993).

11. B. Lenon. Textbooks have a huge impact on education. http://www.telegraph.co.uk/education/educationopinion/11739310/Textbooks-have-ahuge-impact-on-education.html), (2015).

12. A. Littlejohn. The analysis of language teaching materials: Inside the Trojan Horse. In B. Tomlinson (Ed)., Materials development in language teaching. Cambridge: Cambridge University Press. pp.190-216, (1998).

13. Modern Language Association Ad Hoc Committee on Foreign Languages Foreign languages and higher education: New structures for a changed world. Profession 2007, pp.234-245, (2007).

14. A. J. Rockinson- Szapkiw*, J. Courduff, K. Carter, D. Bennett. Electronic versus traditional print textbooks: A comparison study on the influence of university students' learning. Computers \& Education 63, pp. 259-266, (2013).

15. I.M. Solodkova, L.R. Ismagilova. Acquisition of Socio-Cultural Competence via Dynamic Learning Environment. The European Proceedings of Social \& Behavioural Sciences, Vol. 12,.pp.389-395, (2016).

16. Velde \& Ernst. The future of eBooks? Will print disappear? An end-user perspective. Library Hi Tech, 27, pp.570-583, (2009). 